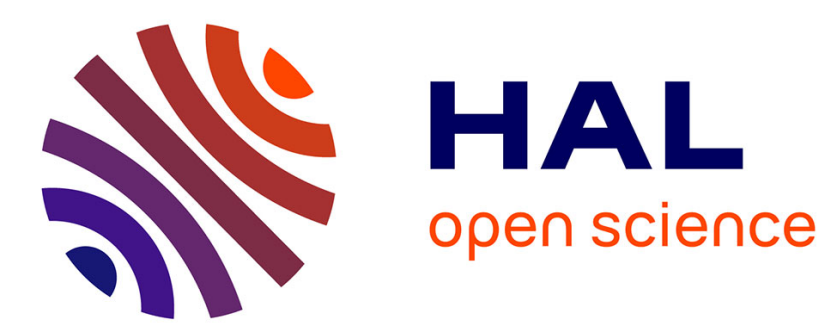

\title{
Lean Management Effects - An Empirical Evidence from Machine Building Industries in Europe
}

\author{
Andreas Mueller, Stanislaw Strzelczak
}

\section{To cite this version:}

Andreas Mueller, Stanislaw Strzelczak. Lean Management Effects - An Empirical Evidence from Machine Building Industries in Europe. IFIP International Conference on Advances in Production Management Systems (APMS), Sep 2015, Tokyo, Japan. pp.299-307, 10.1007/978-3-319-22759-7_35 . hal-01431109

\section{HAL Id: hal-01431109 \\ https://hal.inria.fr/hal-01431109}

Submitted on 10 Jan 2017

HAL is a multi-disciplinary open access archive for the deposit and dissemination of scientific research documents, whether they are published or not. The documents may come from teaching and research institutions in France or abroad, or from public or private research centers.
L'archive ouverte pluridisciplinaire HAL, est destinée au dépôt et à la diffusion de documents scientifiques de niveau recherche, publiés ou non, émanant des établissements d'enseignement et de recherche français ou étrangers, des laboratoires publics ou privés. 


\title{
Lean Management Effects - An Empirical Evidence from Machine Building Industries in Europe
}

\author{
Andreas Mueller, Stanisław Strzelczak \\ Warsaw University of Technology, Faculty of Production Engineering, Warsaw, Poland \\ a mueller 84@yahoo.de, s.strzelczak@wip.pw.edu.pl
}

\begin{abstract}
This paper investigates planned and side effects from Lean Management implementations. Case studies from machine building industries in Europe were used as an empirical base. The focus of presented research is to provide a relevant data, that could help to explain, why the side negative effects of Lean Management implementations take place. The empirical evidence presented herein with regard to the issue, is wider than in any available publication. Also the way of analyzing effects in this paper goes beyond the existing literature.
\end{abstract}

Keywords. Lean Management effects • Lean Management assessment

\section{$1 \quad$ Introduction}

Lean Production or Lean Management is often and worldwide used by companies nowadays. From successful Lean enterprises significant results can be reported, which makes Lean Management interesting for many business sectors. Toyota is often named as the benchmark, which reports $60-90 \%$ lead time reductions, decrease of inventory levels by $10-50 \%$, or improvements of productivity by $5-25 \%$ [1]. Toyota considers Lean as a philosophy, following the principle of just reducing the time line from receiving a customer order to customer delivery, by removing any waste [2].

Lean Management is fuzzy understood by Western, who modified the original intention of the original Japanese concept and tend to understand it like a top-down driven restrictive framework for short or medium term projects, typically targeting localized or punctual improvements. The responsibility for success is normally assigned to project managers who are set in charge of expected improvements. Aimed Lean effects are commonly linked to cost savings, growth targets and utilization improvements. However, the sustainability of expected gains is not surely protected. Negative side effects become visible, which typically appear in a form of additional costs, decreased quality of products or services, customer dissatisfaction and others [3]. The above mentioned misperceptions of what Lean Management is and how it should be implemented and managed, seem to corrupts sustainability and long-term success of implemented Lean Management initiatives. This paper provides an extended empirical evidence of Lean effects, including the side negative effects. It is based on a broad basis of case studies, which were aiming a detailed and multi-perspective evaluation of Lean Managements projects. 


\section{$2 \quad$ Existing knowledge}

The Japanese approach to implementation of Lean Management is often described in five steps [4]: (i) identify a change agent; (ii) find a teacher to facilitate learning; (iii) build a challenge to motivate organization; (iv) map the entire value stream of products; (v) start removing waste at a point that quickly makes an impact and continue then with the rest. The Lean Management in Western world allows various modes of implementation, caused by literature and influence of consulting, which modifies the original Japanese concept of Lean Management [6]. Instead of thinking in terms of value streams and flows, Western managers and executives often focus on short-termsavings, or functions and departments which are in charge of implementation. Managers and project leaders receive bonuses to achieve targets, while the value stream perspective is avoided due to complexities. This is in line with tradition of management control based on standard costs accounting and common focus on utilization of machinery and workers as a major performance indicator [5]. Researchers sometimes describe today interpretation of Lean Management as "considerable variation in scientific and grey literature" being either applied as "philosophy, toolbox, strategic goal or a change process", or even considered as a multidimensional-concept compromising hybrid models, which lead to more vague Lean thinking.

Away from the Lean Management original intentions, the Lean Enterprise Model proposed by the Lean Enterprise Institute introduces a different sequence for implementations: identification of a problem, devising processes to be improved, develop people to continuously improve, allocate managers with right thinking to drive correct leadership, to finally embed the Lean thinking in the company [7]. It is questionable how to combine typical Western approaches with the ideas of Toyota and align the company in long term with Lean thinking, where typically waste in selected processes from value stream analysis is removed i.e. by applying Kanban, Just in Time, SinglePiece-Flow, Levelling, 5S, Kaizen, TPM and diverse other principles.

Many Lean Management publications focus on advantages [5] and suggest that its implementations surely lead to improved performance $[8,9,10,11,12,13]$. Some papers even state that "the research question of primary interest in the literature is no longer whether lean can benefit performance“" [14]. Interestingly all reviewed papers report the effects of Lean Management implementations which were targeted, while eventual side effects are not considered. This exhibits at methodological failure. If one does not look at the side effects, which can be observed elsewhere, they are just not seen at all. The recent empirical evidence neglects the unilaterally positive outlook of Lean by a multi-perspective assessment confirms the existence of side negative effects [3].

The danger of side effects of Lean Management implementations is possibly manifested in spectacular ways. Volkswagen recently reported shortages of components resulting in shutdown of plants. Mercedes and other carmakers report long customer lead times in Europe and USA. BMW extended shipping costs budget for aircraft carriage for urgent deliveries [15]. Bosch established internal task forces to cope with material shortages. ZF Friedrichshafen claims that a many of their strategic suppliers face a difficulty to cope with demand. In USA million car recalls in 2013-2014, caused by faulty airbags or other quality issues were reported [16]. Unfortunately no 
single publication has systematically identified or quantified the root causes of above listed observations. Although the unwelcome effects were not deeply explained, from the described circumstances they seem to be rooted in some particular Lean Management implementations, like e.g. leaning the supply base.

The above exhibits both, the practice gap and the research gap, and calls for extended empirical evidence and further methodological research.

\section{$3 \quad$ Methodology and findings}

The problem stated evidently requires for a sound empirical evidence. It is due to the unilateral view of Lean Management effects presented in the literature, as well as because of the potential difficulties to explain why side negative effects occur.

After the literature review, which could help to identify side negative effects of Lean Management implementations, a series of case studies was considered. All together 16 machine building companies were approached, which are listed in Table 1.

Table 1. Researched companies

\begin{tabular}{|c|c|c|c|}
\hline Company & Workforce & Lean Topic & Interviewees \\
\hline A-Case 1 & $1000+$ & $\begin{array}{l}\text { Product } \\
\text { Development }\end{array}$ & $\begin{array}{l}\text { Chief technical officer } \\
\text { Head of product development }\end{array}$ \\
\hline B-Case2 & $600+$ & Procurement LCC & $\begin{array}{l}\text { Head of procurement } \\
\text { Senior category manage }\end{array}$ \\
\hline A-Case3 & $1000+$ & Assembly Tact & $\begin{array}{l}\text { Head of assembly } \\
\text { Head of outgoing goods }\end{array}$ \\
\hline C-Case4 & $500+$ & Assembly LCC & $\begin{array}{l}\text { Head of assembly } \\
\text { Diverse sales managers }\end{array}$ \\
\hline C-Case 5 & $500+$ & $\begin{array}{l}\text { Engineering } \\
\text { Relocation }\end{array}$ & $\begin{array}{l}\text { Head of engineering } \\
\text { Head of business excellence IT }\end{array}$ \\
\hline A-Case 6 & $1000+$ & Production LCC & $\begin{array}{l}\text { Head of assembly } \\
\text { Head of human resources }\end{array}$ \\
\hline D-Case 7 & $1000+$ & $\begin{array}{l}\text { Machine } \\
\text { Investment }\end{array}$ & $\begin{array}{l}\text { Head of production } \\
\text { Head of quality management }\end{array}$ \\
\hline B-Case8 & $600+$ & Staff Exchange & $\begin{array}{l}\text { Head of assembly } \\
\text { Head of production }\end{array}$ \\
\hline A-Case 9 & $1000+$ & $\begin{array}{l}\text { Sales } \\
\text { KPIs }\end{array}$ & $\begin{array}{l}\text { Head of sales } \\
\text { Managing director }\end{array}$ \\
\hline F-Case10 & $200+$ & $\begin{array}{l}\text { Development of } \\
\text { control units }\end{array}$ & $\begin{array}{l}\text { Head of assembly } \\
\text { Head of product development }\end{array}$ \\
\hline A-Case11 & $1000+$ & $\begin{array}{l}\text { Optimization of precision measuring for } \\
\text { geometrical levelling }\end{array}$ & $\begin{array}{l}\text { Head of production } \\
\text { Head of product development }\end{array}$ \\
\hline C-Case12 & $500+$ & $\begin{array}{l}\text { Shift from control of statistical data to } \\
\text { electrical regulation }\end{array}$ & $\begin{array}{l}\text { Head of commissioning } \\
\text { Head of product development }\end{array}$ \\
\hline D-Case 13 & $1000+$ & Sale of more standard machines & $\begin{array}{l}\text { Head of key account } \\
\text { Head of assembly }\end{array}$ \\
\hline E-Case14 & $300+$ & Relocation of machine Centre to LCC & $\begin{array}{l}\text { Head of production } \\
\text { Managing director }\end{array}$ \\
\hline E-Case15 & $300+$ & Closing of plant, relocation to $\mathrm{LCC}$ & $\begin{array}{l}\text { President operations } \\
\text { Head of machining }\end{array}$ \\
\hline B-Case16 & $600+$ & Build up Machining in LCC & Head of machining \\
\hline
\end{tabular}


The case studies are grounding the research plan, which is presented in Table 2. The professionals from approached companies have been involved in semi-structured interviews and later in expert panels. Results of the two series of meetings compose the baseline of research. All interviews were centered on three key issues. Firstly, the intention to identify the field of project in devised environment. Secondly, the targeted effects as planned before the project. Thirdly, the actual effects - appearing after project. All the three issues have been based on a multi-perspective viewing of the potential side effects. This was crucial for their identification and further assessment. The applied approach is fundamentally different to published researches of that kind.

Table 2. Plan of research

\begin{tabular}{lll}
\hline \multicolumn{1}{c}{ Phase } & \multicolumn{1}{c}{ Scope } & \multicolumn{1}{c}{ Methods / Tools } \\
\hline Initial & $\begin{array}{l}\text { Problem conceptualization } \\
\text { Theory and practice of Lean Mgmt. } \\
\text { Evidence of effects in theory }\end{array}$ & Analysis of literature \\
\hline Empirical & Case studies & $\begin{array}{l}\text { Semi-structured interviewing } \\
\text { Expert panels (2 }\end{array}$ \\
\hline Analysis of results & $\begin{array}{l}\text { Results assessment } \\
\text { Summary of findings }\end{array}$ & Simple statistical analysis \\
\hline Synthesis of results & Conclusion & Theoretical synthesis \\
\hline
\end{tabular}

Due to confidentiality, companies and performance indicators remain unnamed or being published in a synthetic way. Using this basis, some statistical analysis of the gathered data could be provided.

All investigated case studies exhibited seven common characteristics of implementations. All of them were following a common management control structure, which is illustrated below:

(I) Planning

(1) Financial business plan

(2) Steering committee, consisting of:

-Minimum one executive manager

-Controlling associates

-Project Manager

-Member of interfacing departments

(3) Milestone plan for implementation

(4) Basic risk assessment

(II) Control

(5) Regular project meetings, including:

-Progress of implementation

-Financial results review, mainly cost and benefits

-Coaching from steering committee to achieve aimed targets

(6) Budget conformity according to annual budget plan

(7) Verification of financial results

The case studies enabled to identify both, the planned effects of Lean Management implementations, as well as the side negative effects. All of them are listed in Table 3. 
Table 3. Overview of targeted and side effects

\begin{tabular}{|c|c|c|c|}
\hline Case & Field and Topic & Targeted Effects & Negative Effects \\
\hline 1 & $\begin{array}{l}\text { Sales } \\
\text { KPIs }\end{array}$ & $\begin{array}{l}\text { Low development cost } \\
\text { Transparent spending }\end{array}$ & $\begin{array}{l}\text { Additional capex costs } \\
\text { Quality issues } \\
\text { Customer dissatisfaction }\end{array}$ \\
\hline 2 & $\begin{array}{l}\text { Development of } \\
\text { control units }\end{array}$ & $\begin{array}{l}\text { Saving supply cost } \\
\text { LCC quote }\end{array}$ & $\begin{array}{l}\text { Additional one-time costs } \\
\text { Penalties, Fall outs } \\
\text { Quality issues }\end{array}$ \\
\hline 3 & $\begin{array}{l}\text { Optimization of precision } \\
\text { measuring for geometrical } \\
\text { levelling }\end{array}$ & $\begin{array}{l}\text { Cost savings } \\
\text { Double output } \\
\text { Productivity increase }\end{array}$ & $\begin{array}{l}\text { Additional capex costs } \\
\text { Increased stock }\end{array}$ \\
\hline 4 & $\begin{array}{l}\text { Shift control of statistical data } \\
\text { to electrical regulation }\end{array}$ & $\begin{array}{l}\text { Saving personnel costs } \\
\text { Saving production costs } \\
\text { Low cost suppliers }\end{array}$ & $\begin{array}{l}\text { Additional costs } \\
\text { Customer dissatisfaction } \\
\text { Reduced sales volume } \\
\text { Non-acceptance by own staff }\end{array}$ \\
\hline 5 & $\begin{array}{l}\text { Sale of more standard ma- } \\
\text { chines }\end{array}$ & $\begin{array}{l}\text { Saving production costs } \\
\text { Utilization of plants } \\
\text { Standardization }\end{array}$ & $\begin{array}{l}\text { Additional capex costs } \\
\text { Quality issues } \\
\text { Missing responsibility }\end{array}$ \\
\hline 6 & $\begin{array}{l}\text { Relocation of machine Centre } \\
\text { to LCC }\end{array}$ & $\begin{array}{l}\text { Saving production costs } \\
\text { Low investment cost } \\
\text { Growth in market }\end{array}$ & $\begin{array}{l}\text { Additional costs } \\
\text { Quality issues } \\
\text { Non-acceptance by own staff }\end{array}$ \\
\hline 7 & $\begin{array}{l}\text { Closing of plant, relocation to } \\
\text { LCC }\end{array}$ & $\begin{array}{l}\text { Saving production cost } \\
\text { Technological advantage } \\
\text { Utilization }\end{array}$ & Additional one-time and capex costs \\
\hline 8 & Build up Machining in LCC & $\begin{array}{l}\text { Revenue increase } \\
\text { Better motivation }\end{array}$ & $\begin{array}{l}\text { Additional training costs } \\
\text { Quality issues } \\
\text { Customer dissatisfaction }\end{array}$ \\
\hline 9 & $\begin{array}{l}\text { Sales } \\
\text { KPIs }\end{array}$ & $\begin{array}{l}\text { Revenue increase } \\
\text { Motivation }\end{array}$ & $\begin{array}{l}\text { Additional costs } \\
\text { Customer dissatisfaction } \\
\text { Quality issues }\end{array}$ \\
\hline 10 & $\begin{array}{l}\text { Development of } \\
\text { control units }\end{array}$ & $\begin{array}{l}\text { Technological advantage } \\
\text { Saving personnel cost }\end{array}$ & $\begin{array}{l}\text { Additional capex cost } \\
\text { Customer dissatisfaction } \\
\text { Quality issues }\end{array}$ \\
\hline 11 & $\begin{array}{l}\text { Optimization of precision } \\
\text { measuring for geometrical } \\
\text { levelling }\end{array}$ & $\begin{array}{l}\text { Saving personnel costs } \\
\text { Higher quality }\end{array}$ & $\begin{array}{l}\text { Quality issues } \\
\text { Additional cost }\end{array}$ \\
\hline 12 & $\begin{array}{l}\text { Shift from control of statistical } \\
\text { data to electrical regulation }\end{array}$ & Saving personnel costs & $\begin{array}{l}\text { Additional one- time cost } \\
\text { Quality issues }\end{array}$ \\
\hline 13 & $\begin{array}{l}\text { Sale of more standard ma- } \\
\text { chines }\end{array}$ & $\begin{array}{l}\text { Lower production costs } \\
\text { Mass production benefit } \\
\text { Utilization of plant }\end{array}$ & $\begin{array}{l}\text { Customer dissatisfaction } \\
\text { Higher stock } \\
\text { High qualified engineers leave }\end{array}$ \\
\hline 14 & $\begin{array}{l}\text { Relocation of machine Centre } \\
\text { to LCC }\end{array}$ & $\begin{array}{l}\text { Lower production costs } \\
\text { Lower personnel costs }\end{array}$ & $\begin{array}{l}\text { Quality issues } \\
\text { Customer dissatisfaction } \\
\text { Higher stock }\end{array}$ \\
\hline 15 & $\begin{array}{l}\text { Closing of plant, relocation to } \\
\text { LCC }\end{array}$ & $\begin{array}{l}\text { Lower production costs } \\
\text { Lower personnel costs }\end{array}$ & $\begin{array}{l}\text { Quality issues } \\
\text { Image damage, penalties } \\
\text { Loss of qualified staff }\end{array}$ \\
\hline 16 & Build up Machining in LCC & Lower personnel cost & $\begin{array}{l}\text { Quality issues } \\
\text { Additional capex cost }\end{array}$ \\
\hline
\end{tabular}


The project based setup within companies indicates that planning and control are essential for Lean Management projects. The five most common scopes of targeted effects can be categorized as follows:

- Slimmed waste in different departments, along exact processes or within functions

- Reengineered products to minimize costs of goods sold

- Reduced fixed costs or minimized other expenditures by outsourcing

- Improved performance/competitiveness by investment in technology or automation

- Ensured cash flows due to increased sales by high or steady order entries

All investigated cases targeted single elements or hybrids of the above shown scopes of effects.

The most frequent side negative effects resulting from the reviewed projects can be categorized as:

1. additional costs, i.e. unplanned costs, which in some instances even outranked the planned benefits (in nearly all projects);

2. quality issues (in more than every second project);

3. fall-outs and/or resulting penalties (in every third project);

4. higher stock or loss of competencies (in every fourth project).

The quantification of these effects is illustrated below in Fig.1.

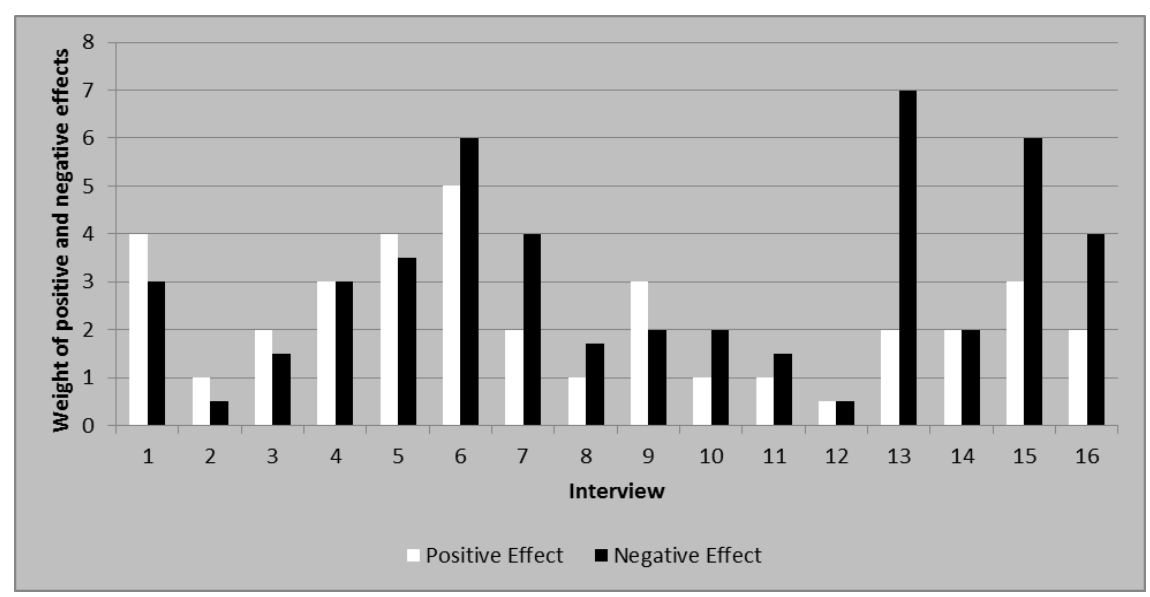

Fig. 1. Absolute quantification of Lean Management target and side effects

In order to illustrate the impact of side negative effects, i.e. in contrast to planned positive effects, a weight scale from zero to seven has been applied, where 0 is the minimum rank and 7 the maximum. The findings provide a proof that negative effects exist and often outrank the planned targets. In first instance the above shown absolute quantifications of effects [Fig.1] have been broken down to major categories of side effects, as illustrated in Table 4. 
Table 4. Breakdown of side negative effects

Interview Extra Cost Quality Issue Fall Outs Higher Stock Competence Loss Others Sub-Total

\begin{tabular}{cccccccc}
\hline $\mathbf{1}$ & 2 & 0,3 & 0,6 & 0 & 0 & 0,1 & 3 \\
\hline $\mathbf{2}$ & 0,1 & 0,2 & 0,1 & 0 & 0 & 0,1 & 0,5 \\
\hline $\mathbf{3}$ & 1 & 0 & 0 & 0,4 & 0 & 0,1 & 1,5 \\
\hline $\mathbf{4}$ & 1 & 0 & 1,6 & 0 & 0,2 & 0,2 & 3 \\
\hline $\mathbf{5}$ & 2,7 & 0,3 & 0 & 0 & 0,5 & 0 & 3,5 \\
\hline $\mathbf{6}$ & 3 & 0 & 0 & 0 & 2 & 1 & 6 \\
\hline $\mathbf{7}$ & 4 & 0 & 0 & 0 & 0 & 0 & 4 \\
\hline $\mathbf{8}$ & 1,5 & 0 & 0 & 0 & 0 & 0,2 & 1,7 \\
\hline $\mathbf{9}$ & 0,8 & 0,2 & 1 & 0 & 0 & 0 & 2 \\
\hline $\mathbf{1 0}$ & 0,5 & 0,6 & 0,8 & 0 & 0 & 0,1 & 2 \\
\hline $\mathbf{1 1}$ & 0,8 & 0,5 & 0 & 0 & 0 & 0,2 & 1,5 \\
\hline $\mathbf{1 2}$ & 0,2 & 0,3 & 0 & 0 & 0 & 0 & 0,5 \\
\hline $\mathbf{1 3}$ & 0 & 0 & 4 & 2 & 1 & 0 & 7 \\
\hline $\mathbf{1 4}$ & 0 & 0,4 & 1 & 0,6 & 0 & 0 & 2 \\
\hline $\mathbf{1 5}$ & 0 & 0,9 & 2,7 & 0 & 2 & 0,4 & 6 \\
\hline $\mathbf{1 6}$ & 3,3 & 0,5 & 0 & 0 & 0 & 0,2 & 4 \\
\hline Total & 20,9 & 4,2 & 11,8 & 3 & 5,7 & 2,6 & 48,2 \\
\hline \% of Total & $43 \%$ & $9 \%$ & $24 \%$ & $6 \%$ & $12 \%$ & $5 \%$ & $100 \%$ \\
\hline & & & & & & &
\end{tabular}

The main impact of side effects results from unplanned "extra costs" of different nature, i.e. higher than assumed project related investments or capex related costs (43\%), followed by costs of "Fall Outs", e.g. customer penalties or cancelled orders (24\%). The third highest effects can be linked to "Competence Loss" (12\%), which is described as unplanned leave of experts or specialists, carrying on unplanned costs. Fourth ranked category is "Quality Issues" (9\%), mainly appearing during project implementation or after project. Second last category is "Higher Stock" (6\%) consisting of increased stock levels, extended costs for warehousing, and additional staff for internal or external logistical efforts. The last category "Others" (5\%) summarizes other costs involved, i.e. cost of reorganization, recruitment or administration costs.

\section{$4 \quad$ Summary and further research}

The data collected along interviews shows that Lean Management implemented in the European machine building industries follows a project based approach. It exhibits a planning and control systematics, which can be considered as a deviation from the Japanese philosophical approach towards Lean. Projects aim reduced costs, reengineering, outsourcing, technology improvements or increased sales, while the intention of Lean Management should be rather to reduce the timeline between customer orders to customer payment. All cases show that side effects have a major impact and significantly reduce, or in many instances even exceed, the planned effects. The empirical data from case studies provides insights into complexity of Lean Management implementation. The critical factor for elicitation of the side negative effects of Lean Management implementations was the multi-perspective approach to their identifica- 
tion and assessment. Consequently it is needed to extend the research towards causal analysis of the side negative effects. Its results could then facilitate development of a method for multi-perspective and holistic assessment of Lean Management implementations.

\section{References}

1. Liker, J.K., Convis, G.L.: The Toyota Way to Continuous Improvement, McGraw-Hill, p. $12(2011)$

2. Ohno, T.: Toyota Production System, Productivity Press, New York (1988)

3. Mueller, A., Strzelczak, S.: Negative Side Effects of Lean Management. IFIP AICT, vol. 440, pp. 167-174. Springer (2014)

4. Rother M., Shook, J.: Learning to See: Value stream mapping to add value and eliminate Muda. Lean Management Institute (1999)

5. Womack, J.P., Jones, D.T., Lean thinking: banish waste and create wealth in your corporation. Free Press, pp. 16-19, 50-54, 60, New York (1996)

6. Bränmark M., et al.: Researching Lean: Methodological Implications of Loose Definitions, Quality Innovation Prosperity, ISSN 1338-984X Online Press, XVI/2, 35 (2012)

7. http://www.lean.org/whatslean/, Lean Enterprise Institute Inc., Cambridge, USA

8. Mackelprang, A.W., Nair, A.: Relationship between just-in-time manufacturing practices and performance: A meta-analytic investigation. J. Opns Mgmt vol.28/4, 283-302 (2010)

9. Shah, R., Ward, P.T.: Lean manufacturing: context, practice bundles, and performance. Journal of Operations Management, vol.21/2, pp. 129-149 (2003)

10. Fullerton, R.R., Kennedy, F.A., Widener, S.K.: Lean manufacturing and firm performance: The incremental contribution of lean management accounting practices. Journal of Operations Management, vol. 32/7-8, pp. 414-428 (2014)

11. Browning, T.R., Heath, R.D.: Reconceptualizing the effects of lean on production costs with evidence from the F-22 program. J. Operations Management, vol. 27/1, 23-44 (2009)

12. Cua, K.O., McKone, K.E., Schroeder, R.G.: Relationships between implementation of TQM, JIT, and TPM and manufacturing performance. Journal of Operations Management vol.19/6, pp. 675-694 (2001)

13. Jayaram, J., Ahire, S.L., Dreyfus, P.: Contingency relationships of firm size, TQM duration, unionization, and industry context on TQM implementation - A focus on total effects. Journal of Operations Management, vol.28/4, pp. 345-356 (2010)

14. Netland, T.H., Schloetzer, J.D., Ferdows, K.: Implementing corporate lean programs: The effect of management control practices. J. Operations Management, vol. 36, 90-102 (2015)

15. Schäfer, D.: Lack of parts hits VW production, Financial Times, No.20.I.2011 (2011)

16. Healey, J.R.: Toyota widens air bag recall-warns passengers, USA Today 20.X.2014 (2014) 